\title{
Fake news about the COVID-19 pandemic: perception of health professionals and their families
}

\author{
Fake news sobre a pandemia da COVID-19: percepção de \\ profissionais de saúde e seus familiares \\ Fake news acerca de la Pandemia de COVID-19: percepción \\ de profesionales de salud y sus familiares
}

How to cite this article:

Barreto MS, Caram CS, Santos JLG, Souza RR, Goes HLF, Marcon SS. Fake news about the COVID-19 pandemic: perception of health professionals and their families. Rev Esc Enferm USP. 2021;55:e20210007. DOI: https://doi.org/10.1590/1980-220X-REEUSP-2021-0007.

\footnotetext{
Mayckel da Silva Barreto ${ }^{1}$

Carolina da Silva Caram²

José Luís Guedes dos Santos ${ }^{3}$

Rebeca Rosa de Souza ${ }^{1}$

Herbert Leopoldo de Freitas Goes ${ }^{1}$

Sonia Silva Marcon ${ }^{1}$

${ }^{1}$ Universidade Estadual de Maringá, Departamento de Enfermagem, Maringá, PR, Brazil.

${ }^{2}$ Universidade Federal de Minas Gerais, Departamento de Enfermagem, Belo Horizonte, MG, Brazil.

${ }^{3}$ Universidade Federal de Santa Catarina, Departamento de Enfermagem, Florianópolis, SC, Brazil.
}

\begin{abstract}
Objective: To know the perception of health professionals and their families about fake news related to the COVID-19 pandemic. Method: Descriptive-exploratory study with a qualitative approach. Twenty-eight individuals participated, including seven physicians, seven nurses, and 14 family members. Data collection took place between August and October 2020, with audio-recorded interviews. After transcription, the content was analyzed using Content Analysis, thematic modality. Results: Three categories were identified: "Context of the occurrence and dissemination of fake news in times of pandemic"; "Consequences of fake news on the experience of the pandemic"; and "Coping strategies to contain/combat fake news". Conclusion: Sociocultural, political, educational, and technological aspects influence the occurrence and dissemination of fake news, which have consequences such as: misinformation, self-medication, worsening in the professional-patient relationship, increased need for additional research, and fear in the population. To face the current situation, greater control by the State is required, with investigation and punishment of people who disseminate fake news, as well as greater awareness among the population on the subject.
\end{abstract}

\section{DESCRIPTORS}

Pandemics; COVID-19; Health Personnel; Social Media; News. 


\section{INTRODUCTION}

COVID-19 was initially identified in December 2019, in the city of Wuhan, China, quickly spreading to several countries. Thus, the disease was declared a pandemic by the World Health Organization (WHO) in March 2020. The high infectivity of its etiological agent, the coronavirus called SARS-CoV-2, associated with the human population lack of immunity, the lack of knowledge about specific antiviral drugs, and the inexistence of a vaccine led to an exponential growth in the number of cases, especially in places where measures to stop its transmission were not taken early and incisively ${ }^{(1)}$.

Most patients infected with respiratory syndromes, such as COVID-19, initially seek an emergency unit. Therefore, nurses and physicians working in these places are the first professionals to provide care for patients with the new disease $^{(2)}$. In addition, the COVID-19 pandemic is an stressful and traumatic event for professionals in emergency units as it is a novel disease requiring constant attention in the use of Personal Protective Equipment (PPE) and vigilance in protection and social distancing measures ${ }^{(3-4)}$. The lack of human resources and of PPE during the pandemic are a reality experienced in different contexts and countries. In Portugal, for instance, the nurses' association and the unions denounced the absence of support strategies to nurses in the face of the weaknesses experienced in daily life, resulting from professional devaluation and non-investment in their workforce ${ }^{(5)}$.

In addition to the inherent aspects experienced by health professionals working in emergency units, general people's mental health tends to become more fragile during the pandemic ${ }^{(6)}$, probably more significantly among family members of professionals who are on the frontline caring for COVID-19 patients. Concurrently, symptoms of depression, anxiety, and stress have been identified in the general population ${ }^{(7)}$, which can be enhanced given the large amount of information received, which is not always true.

In this regard, the fact of having access to a lot of information nowadays can lead to difficulties in discerning what is true or false in the news broadcast. When it comes to health, the lack or incompleteness of information and, in particular, false information (fake news) can lead to irreparable damage ${ }^{(8)}$, as they offer an unprecedented abundance of distortion of facts ${ }^{(9)}$. Thus, the advance in the use of social media as a means of information came with the challenge of monitoring and responding quickly to false content disseminated in these channels. On the other hand, the growing discrediting movement in the traditional means of communication encourages the adherence to alternative sources, constituting a risk to public health that has to be faced. Therefore, specialists' communication cannot be restricted to the academic environment and professionals in the field ${ }^{(10-11)}$.

Nevertheless, in the current context, although the importance of health care professionals in combating the pandemic is highlighted in the media, they have suffered manifestations of prejudice for their work on the frontline, which to some extent is related to the dissemination of fake news. A study carried out by the Oswaldo Cruz Foundation with 25 thousand health professionals from all over Brazil showed that $90 \%$ see fake news dissemination as an obstacle in the fight against the disease. They even partly attribute to it the fact that they are perceived as a risk to society as they are considered a vehicle for transmitting the virus. A considerable portion of them have already suffered some form of discrimination by neighbors (33.7\%) or on the way to work/ home $(27.6 \%)^{(12)}$.

These numbers show the impact of fake news on the lives of professionals and, consequently, on their families, especially those with whom they live, as the family works as a system and, as such, the experience of each of its members affects the family system as a whole. Thus, the way individuals perceive the world (including fake news related to the pandemic) is influenced by the interactions taking place in their daily lives, especially those with family members. Therefore, analyzing the phenomena from the family perspective, considering the interactions, circularity, and reciprocity of members and systems, increases the possibilities of understanding the reality experienced ${ }^{(13)}$.

Therefore, the comprehension of how health care professionals and their families perceive the growing amount of false news conveyed becomes relevant, as this has the potential to impact their lives and society, since all this propagation of dissonant untruths seems to produce disbelief in scientific facts, as well as an unrestrained sense of lack of direction for references and guidance. Another reason for this investigation is the importance of studying the role of the media and social networks as sources of information and their impact on health teams, which is one of the themes considered a priority in the Nursing research agenda for the COVID-19 pandemic ${ }^{(14)}$.

In view of the above, the objective of this study was to understand the perception health care professionals and their families have of fake news related to the COVID-19 pandemic.

\section{METHOD}

\section{Study Type}

This is a descriptive exploratory study with a qualitative approach.

\section{Population}

Twenty-eight individuals participated, including seven physicians, seven nurses, and 14 family members.

\section{Place}

This study is part of a matrix survey, with a qualiquantitative approach, entitled "Repercussions of the COVID-19 pandemic among emergency units' health professionals and their families", developed in emergency units of two small municipalities located in the northwest region of the state of Paraná. Both institutions are public and serve patients around the clock with open-door policy, being a reference for all cases of emergencies, including respiratory 
problems during the COVID-19 pandemic. It should be noted that the selection of these units was for convenience sampling and because they have similarities in relation to the physical structure, the health team, the work process, and the demand of users, with an average of 150 consultations/ day. At the time of the study, 20 physicians and 16 nurses worked in these services.

\section{Selection Criteria}

A convenience sampling was used for participants' selection, considering the ease of access of researchers to potential participants, since they worked in these units. The number of participants was not defined a priori, and the search for new participants ended when the repetition of elements on the theme was identified, as well as the achievement of the initially proposed objective ${ }^{(15)}$.

The inclusion criteria for the professionals were to be a physician or nurse and to work, regardless of time, in direct assistance to patients in one of the emergency units under study, during the COVID-19 pandemic. As for the family members, it was considered: to be indicated by the health professional participating in the study and to live in the same household. Professionals away from work due to a medical leave, maternity leave, or vacation during the data collection period and those who were not available for an interview after at least three scheduling attempts were excluded. Regarding family members, those who were not located in at least three attempts of contact on different days and times and/or who canceled the scheduled interviews at least three times, which did not happen, would be excluded. Thus, 28 individuals participated in the study, a sufficient number to understand the phenomenon under study.

\section{Data Collection}

Data collection took place between August and October 2020, through an interview guided by a semi-structured script, consisting of two parts, the first related to sociodemographic issues to characterize the population studied and the second consisting of questions addressing the perception of fake news related to the COVID-19 pandemic and actions that could minimize this situation. All interviews were carried out by two students from the last year of the nursing course, who had a work relationship with the services and were properly trained before starting the interviews. In addition, especially at the beginning of data collection, they were together in the interviews and transcribed and discussed each one among themselves and with an experienced researcher before the next one.

Interviews with health professionals were conducted in person, lasted 20 to 32 minutes, took place in the emergency unit itself, at times previously established by them, but during the work period. At its end, professionals were asked to provide the name and telephone number of a family member, over 18 years of age, who lived in the same household.

Family members were contacted at least two days after the health professional's indication, to allow them to be notified in advance about the research and that they would be contacted in the next few days. Interviews with family members were carried out by telephone on a day and time established by the participant and lasted from 09 to 21 minutes. It should be noted that in most cases the interview took place at the time of the first contact.

\section{Data Analysis and Treatment}

Both in-person and telephone-based interviews were audio-recorded after consent, to facilitate the subsequent process of full content transcription and to allow for reliable data analysis. For the analytical process, Content Analysis was used, on thematic modality, with its steps of pre-analysis, material exploration, and treatment of the obtained results being applied ${ }^{(16)}$.

In the pre-analysis, the material was organized and a thorough reading of the interviews took place, and the relationship between the content and the proposed objectives was observed. In the second step, exploration of the material, intensive readings took place and the fragments were grouped, by semantic similarity, into broad categories that allowed the classification of elements according to their similarities and differences, with subsequent regrouping, based on common characteristics. In the last step, the treatment of the results, the inference and the interpretation of the main findings were performed based on the presentation of the statements in descriptive charts, in which specific inferences about the content were added according to the specific, relevant, and current literature on the subject ${ }^{(16)}$.

\section{Ethical Aspects}

The research was developed in accordance with Resolution 466/2012 of the National Health Council and was approved by the Permanent Human Research Ethics Committee of the Universidade Estadual de Maringá (UEM) (Opinion: 4.087.225, year 2020). Before starting the in-person interviews, the professionals read and signed the Informed Consent Form (ICF). In the telephone interviews with family members, the researchers read the ICF in its entirety and asked the participants to verbally confirm whether they agreed to participate in the research. An email address or messaging application contact for sending the ICF signed by the researchers was also requested.

Anonymity of participants was respected and their speeches were identified by code names. In the case of health care professionals, by the professional category - physician or nurse - and, in the case of family members, by the degree of kinship with the professional - mother, wife, child, etc. In both cases, the identification was followed by the insertion of an Arabic number corresponding to the order of inclusion in the search (e.g., Physician 01; Son 01). It should be noted that, as instructed by the Ethics Committee, the researchers took into account the biosafety recommendations regarding the minimization of the risk of contagion by COVID-19 during data collection. 


\section{RESULTS}

The 14 health care professionals who participated were evenly divided between nurses and physicians. Their age ranged from 24 to 48 years, with eight man (five doctors and three nurses) and 13 with white skin color. Training time ranged from two to 15 years, with 13 of them having a graduate certificate and working for more than a year in the emergency unit. Among the family members, the age ranged from 20 to 61 years, with 11 women, 08 spouses, 02 children, 02 mothers, 01 sister, and 01 aunt.

The data analyzed led to the identification of three categories, as shown in Figure 1: "Context of the occurrence and dissemination of fake news in times of pandemic"; "Consequences of fake news in the experience of the pandemic"; and "Coping strategies to contain/combat fake news".

\section{Context of the Occurrence and Dissemination of Fake News in Times of Pandemic}

Fake news was perceived by professionals and family members as a widespread reality in society and in the present time, resulting from the digital and technological age and the ease of disseminating information.

This fake news issue doesn't come now from the pandemic. It is part of current times, it is in politics, in the economy, in health. It is a consequence of technological advances, the ease of distributing information. But now with the pandemic it seems that things are worse, the lies have multiplied (Nurse 04).

These days things are different, information travels at a very fast speed, both true and false information. And the worst thing is that whoever produces this false information does it so well that it often seems to be true. The care we need to have makes me remember the saying: "a lie repeated a thousand times and convincingly becomes truth" (Mother 14).

Other interviewees think that aspects inherent to the cultural, socioeconomic, political, and educational context in which people live interfere with whether they believe or not in fake news about the pandemic. They mentioned that "lay" people and people of lower socioeconomic status tend to believe more easily in fake news and thus disseminate it.

Generally, the person who believes this libelous news is the one with the least cultural understanding, often from a lower socioeconomic level. Then you have to work twice: tell him/her the truth and even try to convince him/her that it is real, remove that stigma that remained (Physician 07).

Those who falls for these fake news, mainly, are the more lay people, who sometimes do not have so much knowledge, who are not in the health area or closer to someone who knows about care, knows what is true or not, so they end up sharing (Son 01).

The lay person keeps receiving this false news, there are many people who believe! Even more the political issues, that one says one thing, the other says another. So, the person prefers to believe in what their political ideology is preaching and ends up confused, they think that sometimes it is television exaggeration to interfere in politics and do not take the disease seriously (Husband 06).

\section{Consequences of Fake News in View of the EXPerience of THE PANDEMIC}

Among the harmful consequences of fake news, professionals and family members highlighted that its occurrence increases misinformation and makes it difficult for lay people to understand and clarify issues related to prevention, treatment, and coping with the COVID-19 pandemic.

I think these fake news disturbs our work, because people receive the news through messages, audios, videos, and "buy" it as real. This ends up hindering even the patients' understanding of ways to prevent and treat COVID (Nurse 04).

This is complicated, makes health care difficult, there are many people who believe in lies and instead of going to the hospital or health center when they have symptoms, they prefer to believe in fake news and try to treat the disease at home, without any medical help (Sister 04).

I believe that [the fake news] makes things difficult, especially in terms of treatment. The simplest people may believe that just

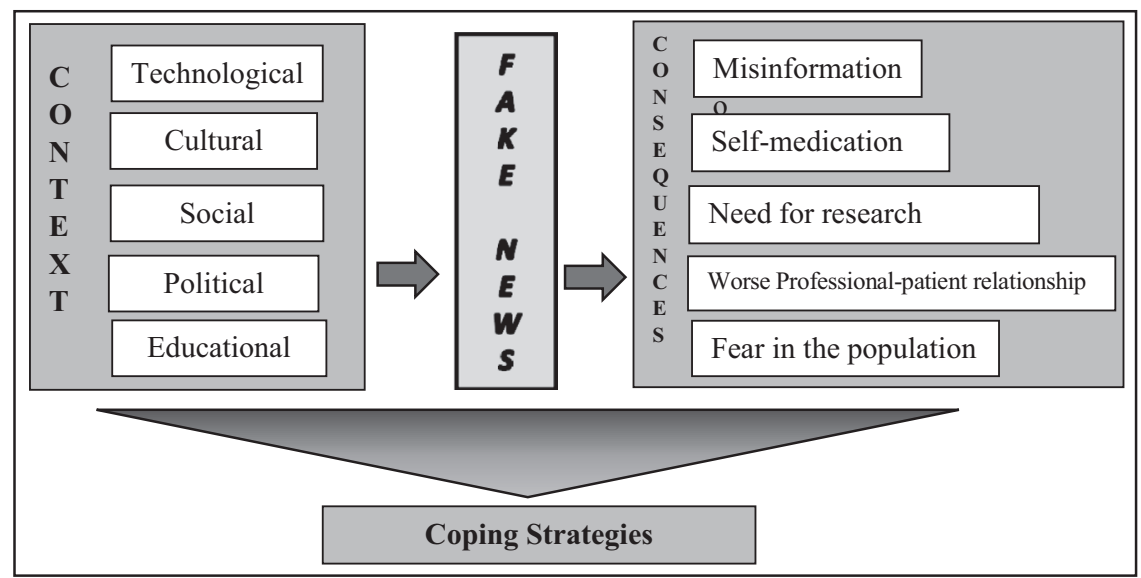

Figure 1 - Representation of the phenomenon investigated and the relationship among the categories identified. 
drinking tea, lemon, vinegar, that sort of thing, can cure the disease. Many people believe this, so they start using it, which can be harmful due to the delay in seeking treatment (Wife 13).

Physician 01 highlighted that among the consequences of fake news is people's self-medication, with drugs with no evidence of effectiveness to prevent or treat COVID-19.

There is the problem of medications. Many medications disappeared from pharmacies and for people who really needed it, there wasn't any. People were desperate for ivermectin, chloroquine, azithromycin, vitamin D. I've seen a study saying that there are people with excess vitamin $D$, because of exaggerated self-medication, thinking that it would prevent infection. So people rushed to the pharmacies to buy these drugs at random, without a prescription, without a suitable professional having indicated them, this is extremely worrying (Physician 01).

Another consequence mentioned was the time spent to search, in reliable sources, for the information received, to clarify possible doubts. This was important to respondents due to a lack of confidence in the alternative means currently used to disseminate information.

It makes our work as a doctor very difficult, because we end up getting exhausted from researching so much information. We see some news, we don't completely believe in it, so we have to take some time, take some energy to look for the real news and check every data about the pandemic (Physician 02).

I think fake news disrupts our lives, because the person is in doubt whether that information is true or not. For example, they talk about the number of cases here in the city, some say that the numbers are wrong, that they are manipulating to increase them. But, people who have family members working in the health area see them daily saying that there are many cases attended per day. So, it is a reality that we have to make some research to know the truth (Mother 03).

Some health professionals were emphatic in pointing out that the sharing of fake news interferes with the patient's relationship with the professional. This happens because, in some cases, patients lose confidence in the proposed treatment and in the guidelines provided.

There are patients who come here and do not want to be consulted. He comes for the medical certificate, but he usually has the treatment defined, a treatment he saw on the internet. This makes the doctor-patient relationship a little difficult (Physician 04).

Many patients already come with fake news on the tip of their tongue and question us, they say they have updated information by the Ministry of Health, but it's all fake news, with no rationale (Nurse 03 ).

These fake news disturb us, because when you are going to give information or guidance, the person looks at you with suspicion and says they don't believe in you. These days, a lady came with a story that this heat was God who sent, because the virus cannot stand more than $36^{\circ} \mathrm{C}$. Then I advised her that even with the heat, you have to follow the recommendations and I think that she didn't pay attention to me (Nurse 06).

Finally, some participants highlighted that fake news has a negative impact on the individual and collective spheres, as such news has the potential to generate fear and anxiety in the population or make most people disbelieve the protection measures.

False news disturbs people. For example, a person can trigger illnesses that he or she didn't have just from the neurosis of being worried with false news. In addition, there is that confusion of information in the media, then comes social panic (Wife 05).

Fake news] makes life difficult for everyone, because there is increased panic in the population, people get scared, and everything that causes panic can destabilize the society (Physician 03).

I work in a pharmacy, there we listen to everything, these days a guy came talking about the temperature, that above $36^{\circ} \mathrm{C}$ the virus dies, then he said that now he doesn't need to worry so much because it's hot, that kind of thing. It's an absurd! But, these news are affecting people in a chain (Husband 11).

\section{Coping Strategies to Contain/Combat Fake News}

Several strategies to help fighting and combating fake news during the COVID-19 pandemic were mentioned by the participants. One of these strategies would be better control by the State over the dissemination of false news, including punishment for those who create and share it.

I think the State should have better control, have a way to find out who does and who shares these lies (Sister 04).

I believe people doing this should be punished, because it's not a joke. Many people play with something serious, this pandemic has killed thousands of people in Brazil and in the world, it is not possible to play games with this issue (Nurse 05).

Look, it's complicated, because the internet, you can put whatever you want there, but I think there would have to be a way to control it, so that only the rights things be available, I don't know, a software, something so that these fake news wouldn't spread so much, an inspection and also punishment, maybe that way it decreases (Wife 02).

A participant suggested that denunciation when receiving fake news should be encouraged, which would help in the process of investigation and punishment of those involved.

There should be a reporting work. Reporting is very important, because it helps to know what news is circulating and those who have the ability to investigate and punish these people, to do something, because this is not healthy, this is not cool (Wife 08).

Participants also considered that raising the awareness of the population about the risks of fake news for individual and collective health would be an important coping strategy. This could be done in traditional media (television and radio) and on the internet, including by health professionals 
in the municipality, who are recognized and respected by the community.

The State should put more information on broadcast television, on radio, to try to make people aware of not believing in everything they see on the internet (Aunt 09).

I believe there could be more awareness. They could use posters, real news both on television and on the internet and messaging apps, a real awareness, a chain of the correct way to convey information that is really true (Nurse 02).

The health personnel could do some campaigns, which was not even done on television about what fake news was, the health personnel in our city, who we know and trust, make some manifestation, assist the population to clarify doubts and show what is right and what is wrong for the population (Wife 10).

Finally, another coping strategy suggested was the individual search for reliable information, based on research and readings from sources considered reliable or based on the search for clarification of doubts from health professionals.

We have to read, research things to know what is right and what is not. What is true and what is not (Husband 06).

They had to look for more information with health professionals, with those who have more concrete information instead of believing in anything (Husband 11).

\section{DISCUSSION}

The results of this study show that the dissemination of fake news is related to the social, cultural, technological, political, and educational context of the current society and that it was highlighted with the COVID-19 pandemic, exacerbating the manifestation of a phenomenon described by the WHO as infodemic, which refers to "overabundance of information, some accurate and some not, that makes it hard for people to find trustworthy sources and reliable guidance when they need it" ${ }^{\prime \prime 17)}$. In 2018, the WHO launched a document on risk communication in public health emergencies, such as the current pandemic. The objective of effective risk communication is to enable people to make proactive decisions in favor of evidence-based protection ${ }^{(18)}$. Infodemic generates misinformation that can negatively affect people's lives, leading to behaviors and attitudes that are incompatible with health guidelines.

Such phenomenon reached, in these times of pandemic, unimaginable proportions, considering the expansion of social networks in the dissemination of information, mainly fake news, which reveal three types of misinformation: a) false allegations about transmission, treatment, and prevention; b) conspiracy theories about China producing the virus in the laboratory and about the possibility of it being transmitted by $5 \mathrm{G}$ towers and; c) the pseudoscience in which therapies and practices are disclosed for the prevention and treatment of coronavirus without scientific basis ${ }^{(19)}$. To have an idea of the volume of information and the difficulty of filtering important information in health surveillance, a study carried out in the pandemic with data collection for 62 days showed that, per day, there were an average of 130,000 posts in Portuguese about the coronavirus in the social media Twitter ${ }^{(20)}$.

Another challenge lies in how people consume this volume of information. The results of the present study highlighted that socioeconomic, cultural, and political factors interfere in the consumption of publications related to the coronavirus. In this regard, a study shows that social actors do not access information equally; there is asymmetry related to its production, dissemination, and consumption ${ }^{(21)}$. Especially in communities where minority groups live, it is perceived that the history of discrimination and restrictions on access to information and health services generate distrust, making them potentially more likely to believe in fake news and less willing to adopt safety measures ${ }^{(22)}$. Political and economic motivation, besides causing polarization among party groups, leading to biased reasoning, influences the dissemination of disinformation, so that the dissemination of content is intentionally carried out to obtain its own benefits at the expense of honest, sincere, and truthful communication ${ }^{(21-22)}$. The dissemination of information without following these precepts leads to disastrous consequences for the lives of individuals and families and for the community health.

The rapid and massive advance of fake news discredits the scientific production and guidelines from health authorities in Brazil and in the world. This, in its turn, reduces the population's adherence to the real guidelines for the prevention of contamination ${ }^{(18,23)}$. In this respect, the participants of this study highlighted, among the consequences of fake news, self-medication to prevent the coronavirus. So far, no study has proven the effectiveness of drugs in the treatment of the disease and this issue has been approached with caution by Brazilian and international health agencies. However, in the health care professionals' daily practice, they need to deal with this attitude from the population.

As an example of the direct impacts of fake news on the health of the population, there is the case of Iran, where the dissemination of false news about the power of alcohol in combating the coronavirus caused the intoxication of thousands of Iranians and hundreds of deaths, including children, following methanol intake ${ }^{(24)}$. Moreover, in the USA, after the president's speech, there was a significant increase in calls to the emergency, of people who got intoxicated by ingesting disinfectants to prevent the coronavirus $^{(21)}$. In addition, in Brazil, there was a presidential indication for the use of chloroquine as a treatment with no scientific evidence ${ }^{(9,21)}$. In this regard, a study mentioned a high demand on the social network Twitter for the term chloroquine, regarding its use, but also publications mocking its indication ${ }^{(20)}$.

Social media allows the publication of information with its various faces, either the useful knowledge for health surveillance or its satire and, regardless of intentionality, it leads to dissemination and repercussion, building truths and narratives. In a context in which the development of scientific knowledge goes side by side with the global spread of the virus, "science becomes increasingly necessary 
although less and less sufficient for the socially binding definition of truth" ${ }^{(9)}$.

In this regard, a study on fake news in Brazil, during the pandemic, identified that most of it uses recognized institutions such as the Oswaldo Cruz Foundation or the Ministry of Health to reference information, with the intention of legitimizing it ${ }^{(23)}$. However, people do not check the veracity and share erroneous information linked to reputable and credible institutions. This promotes disbelief in science and its recommendations ${ }^{(23)}$, contributing to the construction and consolidation of fake news narratives.

The narrative of fake news, built on the potential risk of generating attitude in people, is associated with fear, insecurity, ignorance, and threat caused by the virus ${ }^{(8)}$. Although the population recognizes the importance of science, the narrative produced in their speech does not find such resonance in reality. Therefore, emotional responses during the pandemic can generate useful responses for health agencies, making people more likely to conform to the recommendations if they feel their effectiveness; otherwise, they can be a source of defensive responses, generating risky behaviors $^{(22,25)}$. In this case, the fake news narrative generates discredit in medical behavior and, consequently, damage to the professional-patient relationship, mentioned by the participants of this study.

Science builds its discourse based on rigorous methods for the production of reliable information, which does not happen with everything published on the internet, especially on social media. The discourse produced in fake news is replicated in such a way that it becomes a true narrative, so it is important that the receiver is able to discern the information that will be consumed ${ }^{(26)}$.

Scientific knowledge democratization is a way to promote dialogue between science and the population, to make it tangible for the community, enabling it to take social-political decisions. For this, it is important to expand scientific dissemination, through the translation and adaptation of the language in a way that is also accessible to the general population ${ }^{(26)}$. Ideally, enunciations should be transparent and clear and guide personal dialogues on virtual networks, and risk communication should be balanced with safety and narratives consistent with the discourse of health authorities, in a strict relationship of trust ${ }^{(9)}$. Laboratories and research groups may also consider using social networks to disseminate the knowledge produced, besides the abstracts and scientific articles.

Another point to be considered is that the State is not exempted from information management, but regulating content can be a call for censorship, which in itself is absurd, especially in a context in which information about the pandemic increases daily and is essential for effective control and prevention measures ${ }^{(23)}$. In this regard, it is worth noting that the Ministry of Health created a channel called "Saúde sem Fake News" (Health without Fake News) to answer users' questions and clarify information. Therefore, the importance of expanding the reach of truthful and reliable information is emphasized to weaken the potency of fake news and to strengthen the population so that it is able to deliberately and consciously consume contents ${ }^{(21,23,25)}$. In addition, psychological inoculation has been a strategy to prevent the damage caused by fake news ${ }^{(22,27)}$. Studies show that this inoculation consists of exposing people to the techniques used in (mis)information to make them less susceptible to its consumption ${ }^{(9,26)}$.

This investigation has limitations in data collection, since the interviews with health professionals were carried out within the emergency unit itself. This made some of them to be concerned about returning to work activities, disturbing the participant's involvement. Another limitation is related to carrying out the research with professionals from only two institutions. Thus, it is recommended that future investigations are carried out in contexts favorable to data collection and in different regions of the country, so that there is a broader view of the influence of fake news on family life and in the context of health.

However, despite the limitations, this study allowed raising the discussion on the role of (mis)information in a critical pandemic context, promoting reflection on ways to make knowledge available and ways to prepare people to consume information, so that they become able to make social-political decisions in favor of themselves and the community.

\section{CONCLUSION}

Health care professionals and their families realize that the occurrence of fake news is directly related to the current context of society and its cultural, social, educational, technological, and political aspects. As consequences of fake news about COVID-19, there was an increase in misinformation, greater self-medication, discredit in medical behavior, and worsening of the patients-health professionals relationship. In view of these findings, the professionals and their families pointed out that the fight against fake news shall permeate the State with regard to the publication of false news, with investigation and punishment of those responsible, as well as the expansion of scientific dissemination and awareness of the population for reliable consumption of information on topics involving the COVID-19 pandemic.

\section{RESUMO}

Objetivo: Conhecer a percepção de profissionais de saúde e seus familiares acerca das fake news relacionadas à pandemia da COVID-19. Método: Estudo descritivo-exploratório de abordagem qualitativa. Participaram 28 indivíduos, dos quais sete médicos, sete enfermeiros e 14 familiares. A coleta de dados ocorreu entre agosto e outubro de 2020, a partir de entrevistas audiogravadas. Após a transcrição, o conteúdo foi analisado por meio da Análise de Conteúdo, modalidade temática. Resultados: Foram identificadas três categorias: "Contexto da ocorrência e disseminação das fake nerws em tempos de pandemia"; "Consequências das fake nerws diante da vivência da pandemia"; e "Estratégias de enfrentamento para conter/combater as fake newws". Conclusão: Aspectos socioculturais, políticos, educacionais e tecnológicos influenciam a ocorrência e disseminação das fake nerws, as quais acarretam consequências como: desinformação, automedicação, piora na relação profissional-paciente, aumento da necessidade de pesquisa adicional e medo na 
população. Para enfrentar a atual situação é necessário maior controle do Estado com investigação e punição às pessoas que disseminam fake newws, bem como maior sensibilização da população sobre o tema.

\section{DESCRITORES}

Pandemias; COVID-19; Pessoal de Saúde; Mídias Sociais; Notícias.

\section{RESUMEN}

Objetivo: Conocer la percepción de profesionales de salud y sus familiares acerca de las fake news sobre la pandemia de COVID-19. Método: Estudio descriptivo/exploratorio de abordaje cualitativo. Participaron 28 individuos, entre los cuales siete médicos, siete enfermeros y 14 familiares. La recogida de datos ocurrió entre agosto y octubre de 2020, a partir de entrevistas audio grabadas. Tras la transcripción, el contenido fue analizado por medio del Análisis de Contenido, modalidad temática. Resultados: Fueron identificadas tres categorías: "Contexto de la ocurrencia y diseminación de las fake nerws en tiempos de pandemia"; "Consecuencias de las fake nerws frente a la vivencia de la pandemia”; y Estrategias de enfrentamiento para contener/combatir las fake news. Consideraciones Finales: Aspectos socioculturales, políticos, educacionales y tecnológicos influyen la ocurrencia y diseminación de las fake news, las cuales generan consecuencias tales como: desinformación, automedicación, perjuicio en la relación profesional/paciente, aumento de la necesidad de más investigación y miedo en la población. Para enfrentar la actual situación es necesario mejor control del Estado con investigación y punición a los que diseminan las fake news y mejor sensibilización de la población sobre el tema.

\section{DESCRIPTORES}

Pandemias; COVID-19; Personal de Salud; Medios de Comunicación Sociales; Noticias.

\section{REFERENCES}

1. Kucharski AJ, Russel TW, Diamond C, Liu Y, Edmunds J, Funk S, et al. Early dynamics of transmission and control of COVID-19: a mathematical modelling study. Lancet Infect Dis. 2020;20(5):553-8. DOI: https://doi.org/10.1016/S1473-3099(20)30144-4.

2. Souza LPS, Souza AG. Brazilian nursing against the new Coronavirus: who will take care for those who care? Jornal of Nursing and Health [Internet]. 2020 [cited 2021 Jan 10];10(n. esp):e20104005. Available from: https://periodicos.ufpel.edu.br/ojs2/index.php/enfermagem/ article/view/18444/11237.

3. Asmundson GJG, Taylor S. Coronaphobia: Fear and the 2019-nCoV outbreak. J Anxiety Disord. 2020;70:102196. DOI: https://doi. org/10.1016/j.janxdis.2020.102196.

4. Teixeira AC, Pereira R, Silva JAP. Facing COVID-19: experience report from a Portuguese intensive care unit. Revista Parana Enfermagem [Internet]. 2020 [citado 2021 May 01];3(1):82-90. Available from: http://seer.fafiman.br/index.php/REPEN/article/view/599/553.

5. Ventura-Silva JMA, Ribeiro OMPL, Trindade LL, Nogueira MAA, Monteiro MAJ. International year of the nursing and the pandemic of COVID-19: media expression. Science, care, and health. [Internet]. 2020 [cited 2021 May 21];19:e55546. Available from: https:// periodicos.uem.br/ojs/index.php/CiencCuidSaude/article/view/55546/751375150698.

6. Carvalho PMM, Moreira MM, Oliveira MNA, Landim JMM, Rolin-Neto ML. The psychiatric impact of the novel coronavirus outbreak. Psychiatry Res. 2020;286:112902. DOI: https://doi.org/10.1016/j.psychres.2020.112902.

7. Wang C, Pan R, Wan X, Tan Y, Xu L, Ho CS, et al. Immediate psychological responses and associated factors during the initial stage of the 2019 coronavirus disease (COVID-19) epidemic among the general population in China. Int J Environ Res Public Health. 2020;17(5):1729. DOI: http://dx.doi.org/10.3390/ijerph17051729.

8. Sanches SHDFN, Cavalcanti AELW. The right to health in the information society: fake news and its impacts on vaccination. Revista Jurídica [Internet] 2018 [cited 2021 Jan 18];04(53):448-66. Available from: http://revista.unicuritiba.edu.br/index.php/RevJur/article/view/3227.

9. Vasconcellos-Silva PR, Castiel LD. COVID-19, fake news, and the sleep of communicative reason producing monsters: the narrative of risks and the risks of narratives. Cad Saude Publica. 2020;36(7):e00101920. DOI: https://doi.org/10.1590/0102-311x00101920.

10. Kim Y. Nurses' experiences of care for patients with Middle East respiratory syndrome-coronavirus in South Korea. Am J Infect Control. 2018;46(7):781-7. DOI: http://dx.doi.org/10.1016/j.ajic.2018.01.012.

11. Lana RM, Coelho FC, Gomes MFC, Cruz OG, Bastos LS, Villela DAM, et al. The novel coronavirus (SARS-CoV-2) emergency and the role of timely and effective national health surveillance. Cad Saude Publica. 2020;36(3):e00019620. DOI: http://dx.doi.org/10.1590/0102$311 \times 00019620$.

12. Leonel F. Pesquisa analisa o impacto da pandemia entre profissionais de saúde [Internet]. Rio de Janeiro: Portal FIOCRUZ. 2021. Available from: https://portal.fiocruz.br/noticia/pesquisa-analisa-o-impacto-da-pandemia-entre-profissionais-de-saude.

13. Bousso RS. Family systems theory as a theoretical reference for research with families who experience illness and death. REME [Internet]. 2008 [cited 2021 Jan 21];12(2):257-61. Available from: https://www.reme.org.br/artigo/detalhes/266.

14. Pereira EG, Felix AMS, Nichiata LYI, Padoveze MC. What is the Nursing research agenda for the COVID-19 pandemic? Rev Esc Enferm USP. 2020;54:e03661. DOI: https://doi.org/10.1590/s1980-220x2020pv0103661.

15. Minayo MCS. Sampling and saturation in qualitative research: consensuses and controversies. Revista Pesquisa Qualitativa [Internet]. 2017 [cited 2021 Mar 29];5(7):1-12. Available from: https://editora.sepq.org.br/index.php/rpq/article/view/82/59.

16. Bardin L. Análise de conteúdo. Edições 70: Lisboa; 2016.

17. Organização Pan-Americana da Saúde. Entenda a infodemia e a desinformação na luta contra a COVID-19 [Internet]. Organização PanAmericana da Saúde; 2020 [cited 2020 Dec 23]. Available from: https://iris.paho.org/handle/10665.2/52054?locale-attribute=pt.

18. Organização Mundial de Saúde. Comunicação de riscos em emergências de saúde pública: Um guia da OMS para políticas e práticas em comunicação de risco de emergência [Internet]. Organização Mundial de Saúde; 2018 [citado 2020 Dec 23]. Available from: https:// apps.who.int/iris/bitstream/handle/10665/259807/9789248550201-por.pdf. 
19. Naeem SB, Bhatti R, Khan A. An exploration of how fake news is taking over social media and putting public health at risk. Health Info Libr J. 2020;28:143-9. DOI: https://doi.org/10.1111/hir.12320.

20. Xavier F, Olenski JRW, Acosta AL, Sallum MAM, Saraiva AM. Análise de redes sociais como estratégia de apoio à vigilância em saúde durante a Covid-19. Estud Av. 2020;34(99):261-82. DOI: https://doi.org/10.1590/s0103-4014.2020.3499.016.

21. Lima CRM, Sánchez-Tarragó N, Moraes D, Grings L, Maia MR. Emergência de saúde pública global por pandemia de Covid-19: desinformação, assimetria de informações e validação discursiva. Folha de Rosto. 2020;6(2):5-21. DOI: https://doi.org/10.46902/2020n2p5-21.

22. Van Bavel JJ, Baicker K, Boggio OS, Capraro V, Cichocka A, Cikara M, et al. Using social and behavioural science to support COVID-19 pandemic response. Nat Hum Behav. 2020;4:460-71. DOI: https://doi.org/10.1038/s41562-020-0884-z.

23. Galhardi CP, Freire NP, Minayo MCS, Fagundes MCM. Fact or Fake? An analysis of disinformation regarding the Covid-19 pandemic in Brazil. Cien Saude Colet. 2020;25(Suppl 2):4201-10. DOI: https://doi.org/10.1590/1413-812320202510.2.28922020.

24. Trew B [Internet]. Londres: Independent; 2020 [cited 2020 Dec 20]. Coronavirus: hundreds dead in Iran from drinking methanol amid fake reports it cures disease. Available from: https://www.independent.co.uk/news/world/middle-east/iran-coronavirus-methanoldrinkcure-deaths-fake-a9429956.html.

25. Brandão CWGS, Cruz DACS, Rocha TB. Fake news em tempos de COVID-19: discursos de ódio nas redes sociais como ressonância da desinformação. Revista Internacional Artes de Educar. 2020;6(n.esp II):303-27. DOI: https://dx.doi.org/10.12957/riae.2020.51910.

26. Dantas LFS, Deccache-Maia E. Scientific dissemination in the fight against fake news in the Covid-19 times. Research, Society and Development. 2020;9(7):e797974776. DOI: http://dx.doi.org/10.33448/rsd-v9i7.4776.

27. van der Linden S, Roozenbeek J, Compton J. Inoculating against fake news about COVID-19. Front Psychol. 2020;11:566790. DOI: http:/ dx.doi.org/10.3389/fpsyg.2020.566790. 